\title{
THE THIRD WAY. HUMANITARIAN CORRIDORS IN PEACETIME AS A (LOCAL) CIVIL SOCIETY RESPONSE TO A EU'S COMMON FAILURE
}

\author{
A terceira via. Os corredores humanitários em tempos de paz \\ como uma resposta da sociedade civil (local) ao fracasso geral \\ da União Europeia
}

\begin{abstract}
Migration has been and will continue to be one of the key issues for Europe in the coming decades. A growing number of potential refugees attempts to escape transit countries to reach the European Union by embarking in dangerous journeys to cross the Mediterranean Sea and illegally enter the European Union. Within the European Union resettlement represents a 'durable solution' for vulnerable forced migrants alongside local integration and voluntary repatriation, a protection tool for potential people whose lives and liberty are at risk. In Italy, a group of institutions from civil society and the Italian Ministries of Foreign Affairs and of Interior signed a Protocol of Agreement for the establishment of Humanitarian Corridors to ensure the legal and safe resettlement of asylum seekers. Our article will show how these Humanitarian Corridors proved to be a successful multi-stakeholder engagement to support safe and legal pathways to protection as well as durable solutions for third country nationals in need of protection.
\end{abstract}

Keywords: humanitarian corridor, migration, refugees, innovative practice.

Resumo. A migração tem sido e continuará sendo uma das questões fundamentais para a Europa nas próximas décadas. Um número crescente de refugiados ou de requerentes de asilo, em viagens perigosas através do Mediterrâneo tenta escapar de países de trânsito e entrar irregularmente na União Europeia. Na União Europeia, a recolocação (reassentamento) representa uma "solução duradoura" para os migrantes forçados vulneráveis -e, juntamente com a integração local e o repatriamento voluntário,

* Faculty of Economics and Center for Social Studies University of Coimbra. Coimbra, Portugal.

** University of Pavia. Pavia, Italy. 
uma ferramenta de proteção para pessoas cujas vidas e liberdades estão em risco. Na Itália, um grupo de instituições da sociedade civil e os Ministérios das Relações Exteriores e do Interior assinaram um memorando para o estabelecimento de corredores humanitários para assegurar o reassentamento legal e seguro dos requerentes de refúgio. Nosso artigo mostrará como esses Corredores Humanitários se mostraram uma atividade bem-sucedida para as partes interessadas por garantir percursos seguros e legais de proteção, bem como soluções duradouras para cidadãos de países terceiros que precisam de proteção.

Palavras-chave: corredor humanitário, migração, refugiados, prática inovadora.

\section{Introduction}

The European Union (EU) has faced many challenges and conflicts since its beginning. The level of disagreements and distrust deriving, in particular but not only, from a not well management of migration flows, are presently particularly high. Though, the relation between the EU and the integration process of migrants and refugees in the society is very old. As from the 1970s, several European countries established formal resettlement programs in partnership with United Nations High Commissioner for Refugees (UNHCR). Many of them also adopted Protected Entry Procedures (PEPs), which enable non-nationals to approach a country outside of its territory with a claim for asylum or other forms of international/humanitarian protection, and to be granted an entry permit in cases of a positive response to the claim. Furthermore, several European countries received beneficiaries of international protection through Humanitarian Evacuation Programmes (HEPs) launched in early April 1999 by UNHCR and the International Organisation for Migration (IOM). Recently, in particular since 1999, and with the worsening of violence and conflicts in areas neighbouring the EU, the European Union has been working to create a Common European Asylum System (CEAS) and improve the current legislative framework. Efforts have been made but, so far, comprehensive solutions were not brought in to the problem.

Although national governments tend to think about the asylum and migration issues in domestic terms, this is a pan-European problematic. Since the signature of the Amsterdam Treaty (1997), migration and asylum related issues have always been key subjects discussed at the EU level as the increasing dimension of the matter but also because of the fact that they regularly appear on newspapers headlines. From Tampere European Council (1999) to the strategic guidelines adopted in June 2014 in line with the Lisbon Treaty (2007), these issues have rarely left the top of the political agenda. The EU legislative framework on migration includes Directive 2003/86/EC on 
family reunification; Directive 2003/109/EC on long-term residents; Directives 2004/114/EC on Students and 2005/71/EC on researchers, later recast as Directive (EU) 2016/801 (entry into effect in 2018); Directive 2009/50/EC on highly skilled employment (EU Blue Card); Directive 2011/98/EU on a single application procedure for a single permit and equal treatment of third-country workers; Directive 2014/36/EU on Seasonal workers; Directive 2014/66/EU on intra-corporate transfers. The Qualification Directive (Directive 2011/95/ EU) clarifies the grounds on which international protection is granted to asylum-seekers. The Asylum Procedure Directive (Directive 2013/32/EU) establishes common procedures for granting and withdrawing international protection, while strengthening the rights of asylum- seekers during the asylum procedure. A regular asylum procedure may now not last more than six months. The Reception Conditions Directive (Directive 2013/33/EU) ensures a common standard in Member States for asylum-seekers' access to healthcare, education, employment, etc. While detention is possible only as a last resort and for a period 'as short as possible', criticism has been made of the possibility that asylum-seekers may be kept in prisons if no specialised detention facilities are available. The Dublin III Regulation (Regulation (EU) n. $904 / 2013$ ) establishes the criteria for determining which Member State is responsible for examining an application for international protection to avoid the phenomenon of 'refugees in orbit' (asylum-seekers for which no Member State takes responsibility) and to prevent multiple asylum applications. By default, the first Member State that the applicant entered (the port of entry) is responsible. The implementation of the Dublin Regulation is facilitated by the EURODAC Regulation, a fingerprint database in which Member States register the fingerprints of asylum-seekers and irregular migrants in order to identify the point of entry or the first application made by a claimant.

Nevertheless, the efforts made by the European Commission (EC) to harmonize procedures seem to have had little success so far undermining the potential solutions ${ }^{1}$. The result was an assortment of national and European policies not running coherently and in some case denying previous common EU agreements, leading to misuse of EU conventions and arrangements. For instance, in 2001, the EU adopted legislation laying down common standards to all Member States for giving temporary protection to people fleeing their countries in the event of a mass influx of displaced persons in the Union ${ }^{2}$. So far, surprisingly, no country has called for this directive when facing recent

GUILD, Elspeth, MORENO-LAX, Violeta. Current Challenges for International Refugee Law, with a Focus on EU Policies and EU Co-operation with the UNHCR.

2 Council Directive 2001/55/EC of 20 July 2001 on minimum standards for giving temporary protection in the event of a mass influx of displaced persons and on measures promoting a balance of efforts between Member States in receiving such persons and bearing the consequences thereof. 
massive influx of asylum seekers. This is anomalous but shows very well the Catch-22 of EU countries faced between national sovereignty and European integration policy. Migration and asylum issues still remain part of national policies and no EU government considers abdicating from those obligations in favour of broader policies even in the circumstance of a crisis.

The magnitude of a multifaceted migration flows arriving in the EU has reached an unprecedented peak in recent years. Complementing the average flow of around 3 million migrants a year with more than 1 million potential refugees entering the EU in 2015 alone and nearly another million since January 1 2016, the phenomenon has been considered and qualified as a "crisis", or as an unsolved migratory/refugees "crisis". However, in our opinion, it is not a crisis but a structural dimension or result of a inertia policy of international community. As Monish Bhatia points out "the urgency of the language of 'crisis' disguises years of restrictionist policies and sheer political inaction to resolve a complex humanitarian situation. It also conveniently overlooks the escalation of border controls and policing measures to keep the 'other' out" 3 . In our opinion, the crisis it's related with neighbouring policies: in the Mediterranean, in the East, Africa and in the Middle-East. For example, the situation in Ukraine is still not stabilised and no solution is expected in the short run. Furthermore, the decision of British citizens to leave the EU has added another unprecedented disruption whose effects remain all but settled. In our view, it is not a crisis but a new structuration of power relations in the neighbourhood areas of the EU. Migration is just a consequence and not a source of the crisis.

\section{Migration and Human rights}

The unstoppable movement of refugees, asylum seekers, and other migrants across the securitized European southern borders have instigated a debate about the limits of obligation, acceptation, human rights, national sovereignties, or the European values, precipitating and contributing to the ongoing European humanistic crises. Nowadays, in the era of globalisation, borders constitute permeable passages for capital, services and commodities, however at the same time they have seek to immobilise migrant and refugee populations in the port of entry countries, namely in Italy and Greece. Borders are seen more as walls and not as doors: free movement of people has not been achieved yet. The inertia and incapacity of a collaboration among EU member states can be observed by the emerging idea of "Fortress Europe". This complex concept has several practical examples that help us to define it. For instance, new state control agencies, freshly erected border fences

\footnotetext{
BHATIA, Monish. Seeking Refuge in Europe.
} 
(and walls), detention (or retention) centres and improvised refugee camps make the European Fortress idea a reality. Moreover, hotspots for refugees, fingerprints databases and DNA test $s$ are part of the EU refugees-related terminology. Together, these governance policies and technologies of migration management aim at the criminalisation, classification, stigmatisation, and bio-political control of moving populations. Furthermore, all these measures in the long run, aim to stop migration to Europe transforming a refugee crisis into a migration zero solution.

\section{The critical role of central Mediterranean as a cross path of migratory routes}

Since, at least, 10 years, we are assisting to a growing number of potential refugees' efforts to escape original transit countries to reach Europe by embarking in dangerous journeys to cross the Mediterranean Sea. The "Arab Spring" (growing in Tunisia at the end of 2010 and subsequently exported to other countries within the region) has transformed EU's immediate neighbourhood and brought a high level of instability all across the region. In a short time, the Mediterranean Sea has become the new "Rio Grande".

Following the "Arab Spring", the Central Mediterranean route became the most heavily-trafficked one: immigrants and refugees were fleeing from instability in Libya and Tunisia, as well as from Egypt. The flows increased after Muammar Gaddafi regime's decision to force out most of the 40,000 sub-Saharan immigrants living there, who had no choice but to head to Europe via Libya. Those sub-Saharan are part of a bigger group of a combination of economic migrants, war refugees, economic refugees, climate refugees, religion refugees and their families. They left their distant hometowns to Libya where they try to find an illegal way to reach Europe. Since more than a decade ago, the Central Mediterranean route is also known to be used by people from Niger and Nigeria but also Syria ${ }^{4}$, Afghanistan, South Sudan, Eritrea, Somalia and Iraq fleeing from situations of risk caused by conflicts, terrorism, political instability, poverty, famine and drought.

\footnotetext{
4 The Syrian civil war is still unresolved since 2011 and generated millions of displaced people either internally (IDP) 6.3 million or to neighbourhood countries (e.g. Turkey 2.8 million; Lebanon 1.0 million; Iraq 0,2 million; Jordan 0.6 million; western countries 0.7 million). Cf. UNCHR. Global trends. Forced displacement in 2016.
} 


\section{Figure 1- Main Sea migratory routes in the Mediterranean region}

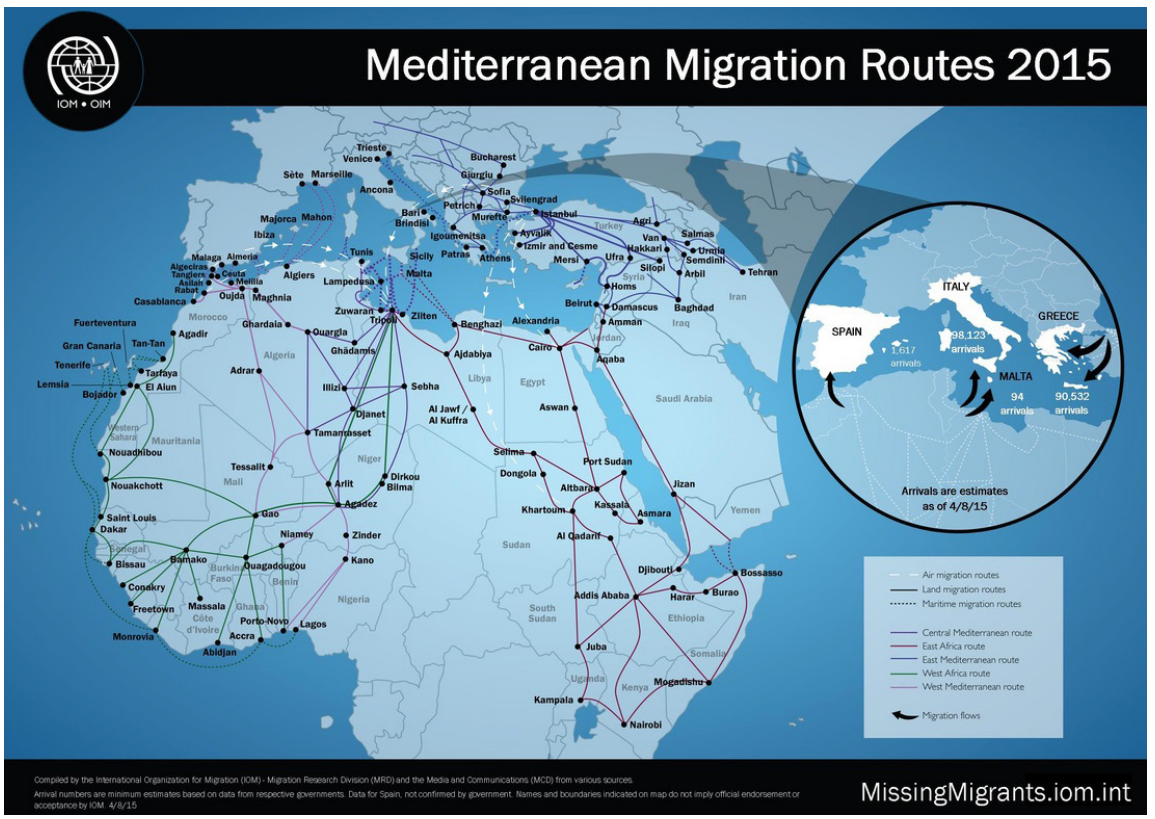

Source: <http://www.thegeographeronline.net/uploads/2/6/6/2/26629356/8926214_orig.jpg>. Retrieved 10.08.2017.

In the early moments of this migratory crisis, smugglers employed innovative tactics for transporting migrants, using cheap and unappropriated large cargo ships heading directly to Malta or Italian shores. Deteriorating living conditions in Libya, combined with the increased sophistication of smuggling networks, led many people to risk their life and try to reach Europe notwithstanding poor weather conditions and the countless news of sinking boats, missing people and human trafficking business. Excluding the limited effects of bilateral agreements on repatriation of illegal immigrants between Italy and some northern African countries in short time, the "Mediterranean traffic" has not been stopped since early 2010's. Trafficking gangs dispatching migrants on perilous journeys across the Mediterranean Sea have changed over time trying to elude the surveillance of EU authorities and to perpetuate their business. So far, southern European countries (Malta, Greece and Italy) has been faced, mostly alone, the burden of the biggest migration crisis since World War II.

With dozens of thousand-people reported to have been rescued or missing during the journey crossing the Mediterranean, a new approach is long overdue. A fundamental turning point in the perception of immigrant journeys was the sinking of a ship near Lampedusa (Isola dei Conigli) on October 2013 killing 368 from a total of 500 migrants. This tragedy had very big media coverage; it was 
the first time that so few people were able to survive. At the end of the month, Italy launched Mare Nostrum search and rescue operation in collaboration with other European countries, which reduced the number of victims on the Mediterranean Sea for a short time. The EU-funded Operation Mare Nostrum rescued more than 100,000 refugees from the sea, but was discontinued in September 2015 amid concerns about the expenditure, and fears that it was acting as a pull-factor, encouraging illegal immigration into Europe. The replacement service, Operation Triton, run by Frontex, had fewer vessels and limits itself to European territorial waters rather than ranging out to near the Libyan coast. Operation Triton was focused on border control, only carrying out search-and-rescue operations if necessary. The consequences of this divergent strategy - from search-and-rescue to border control- de facto increased the number of incidents and deceased migrants in the crossing Mediterranean migration subsequently to 2014 end of Mare Nostrum operation.

According to Frontex the Central Mediterranean route remained under intense migratory pressure in 2015, although the total number of migrants arriving in Italy fell rapidly. The main reasons for the drop were the shift of Syrians to the Eastern Mediterranean route and a shortage of boats faced by smugglers in the latter part of the year. Smuggling networks remain well established in Libya: in 2015 Eritreans, Nigerians and Somalis accounted for the biggest share of the migrants making the dangerous journey thru the Central Mediterranean route. People smugglers typically put migrants aboard old, unseaworthy fishing boats, or even small rubber dinghies, which are much overloaded and thus prone to capsizing. These vessels are generally equipped with poor engines, lack proper navigation systems and often have insufficient fuel to reach Europe ${ }^{5}$. These are the main reasons of mortal accident during the Mediterranean crossing journey.

The tragedy of October 2013 and the following ones highlighted the need of an efficient European response and solidarity among European countries. The EU has enacted a range of measures in an attempt to curb the influx and to allow all the countries to participate through resettlement programs. However, EU did not speak with one voice: each State has promulgated national laws following their particular interests. Almost all European countries responded by increasing border-controls, sea patrols and surveillance as well as port-checks. Furthermore, at the end of 2015 Central and Eastern European countries have implemented border-control mechanisms that resulted in the effective closure of the Eastern Central route. Overall, according to Katsiaficas "State efforts to reduce migration have had mixed results in achieving their stated aims ${ }^{\prime \prime}$. There should be a stronger focus on migrants' rights since they are constantly denied

\footnotetext{
Cf. FRAN Quarterly - Frontex, 2016.

6 KATSIAFICAS, Caitlin. Asylum Seeker and Migrant Flows in the Mediterranean Adapt Rapidly to Changing Conditions.
} 
during their journey. Human-rights groups criticized the reaction of European states as the continuous bordering of Europe makes more difficult for an asylum seeker to reach Europe and apply for international protection.

Migration journeys are lengthy, costly and psychologically devastating. Along the way, people may be abused and exploited by organized crime networks and local population. Migrants may be placed in squalid prisons, locked up and tortured until they are forced to embark on precarious journeys on expensive rubber boats ${ }^{7}$. According to the "Missing Migrants Project" led by IOM in the last years, more than eight thousand individuals died attempting to reach Southern Europe shorelines (3.784 in 2015, 5.143 in 2016 and 2,405 migrant deaths in the Mediterranean in 2017) ${ }^{8}$. These numbers are a small part of the total as it is difficult to know exactly how many women, men and children fleeing poverty, war or famine have drowned while crossing the Mediterranean Sea.

All these deaths are a consequence of international community's collective failure to implement a credible plan of humanitarian aid to migrants and refugees that are looking for better living conditions. At the beginning, governments and media did not give enough attention: they were shocked by the news, but they were thinking it was something that was behind their responsibilities and that were a sporadic event easily to manage and reduce. Civil society organizations have often filled the void of political inaction by providing adequate basic services to those in need (in particular at the moment of their arrival in the coastline of Malta, Italy or Greece). We will now present one cutting-edge project as an example of these bottom-up welcoming refugees movements that tries to become part of the solution to the crisis.

\section{A new type of Humanitarian corridors: a local answer to a global problem}

In July 2015, the European Council adopted a European Resettlement Scheme providing legal and safe pathways to enter the EU in a way to avoid displaced persons in need of protection having to resort to the criminal networks of smugglers and traffickers. The agreed Scheme, supported by the EU budget, allows 22,000 people in need of international protection to resettle from outside of the EU to the EU Member States. According to "Relocation and Resettlement - State of Play" (EC, 8 February 2017), slightly more than 600 people (including 117 arrived subsequent to the EU-Turkey Statement) were resettled in Italy within the Scheme from May 2015 to February 2017 (20 months). It is a small number compared to the people (1000) resettled in Italy

HELLER, Charles, JONES, Chris. Eurosur: saving lives or reinforcing deadly borders?, p. 7.

8 Cf. <https://missingmigrants.iom.int/>. Consulted on: 17.08.2017. 
in 24 months within the Humanitarian Corridors project, a private sponsorship for refugees promoted by civil society 9 .

The idea of the Humanitarian Corridors $(\mathrm{HC})$ as a way to overpass the impasse on the EU relocation scheme was born after the tragedies of October 2013 by the Community of Sant'Egidio in collaboration with Diaconia Valdese and Italian Federation of the Evangelical Churches, the Waldensian and Methodist Churches. The main reason for its implementation is to stop the journey of death and the exploitation of human traffickers who make money out of the lives of these people by providing a legal gateway to safely reach Europe, grant the beneficiaries a humanitarian visa and support them during the integration process into the Italian society. Their first consideration is directed to people who have more difficulty to undertake the journey, this is the reason why $\mathrm{HC}$ focus primarily on the most vulnerable candidates.

A humanitarian corridor is used to be defined as a type of temporary demilitarized zone intended to allow the safe transit of humanitarian aid in, and/or refugees out of a crisis region. Various types of "humanitarian corridors" have been proposed in the Post-Cold War era, put forward either by one or more of the warring parties, or by the international community in the case of a humanitarian intervention. Humanitarian corridors aim at providing a safe pathway for refugees with legal access to a country where they can be safe and enjoy civil and social rights. In this particular case $\mathrm{HC}$ has been possible by applying art. 25 of the Visa Regulation (EC) no. 810/2009 of July 13, 2009 which established the "Community code on visas". The European regulation provides for a Member State the possibility of issuing visa for humanitarian reasons or national interest or because of international obligations. This means that people who meet at least one criteria of UN for being considered "vulnerable" could be entitled to an entry visa with limited territorial validity.

Diaconia Valdese, together with the Community of Sant'Egidio and the Italian Federation of the Evangelical Churches, the Waldensian and Methodist Churches signed on December 2015 a Protocol of Agreement with the Italian Ministries of Foreign Affairs and of Interior for the establishment of Humanitarian Corridor to ensure the legal and safe resettlement of 1,000 vulnerable people from Lebanon, Morocco and Ethiopia to Italy in 2016 and $2017^{10}$.

The humanitarian corridors experience is unprecedented in that as it is fully bottom-up, managed and financed by civil society actors (the project does not weigh in any way on the State). In fact, they created a mechanism in

\footnotetext{
9 MALLARDO, Alberto. Humanitarian Corridors: A Tool to Respond to the Refugees' Crisis.

${ }^{10}$ These three countries were selected due to their role as transit countries for people fleeing Syrian conflict, Sub-Saharan widespread violence and unending civil wars (in Sudan, South-Sudan, Somalia and Eritrea, for example).
} 
which they can determine who exactly enters Europe through the cooperation between a network of NGOs, organizations and institutions that are located in asylum seekers' original countries and preventive controls by also the Italian immigration and security departments.

The $\mathrm{HC}$ is an ecumenical initiative and illustrates that it is possible to guarantee regular entries through legislative instruments already made available by the EU. There is no need to create new laws: it is sufficient to apply Article 25 of the EU visa regulations. This mechanism makes the pilot project replicable at European level enhancing its diffusion and the possibility of saving human lives.

The Community of Sant'Egidio during the HC project's planning spotted carefully the current Italian hosting system. Consequently, they decided to draw up a project that follows asylum seekers during the application's procedures for the international protection and helps them to well integrate in the society. The beneficiary will leave the project only when she/he is completely independent. The Community of Sant'Egidio imposes itself not to repeat the same mistakes of Italian government, but to create an efficient program from which governments can draw inspiration. In fact, one of the main objectives on $\mathrm{HC}$ project is to create an innovative hosting and integration system different from the current one, which will be briefly summarized.

The Italian reception system is divided in first-stage (CARA) and secondstage reception (SPRAR) ${ }^{11}$. After arriving directly to Italy, especially crossing the sea, migrants are brought to $\mathrm{CPSA}^{12}$ structure (first aid and reception center) situated at the main landing places. In CPSA takes place the first rescue, assistance operations and medical treatment. As these few CPSAs constantly face emergency situations with new arrivals, the reception conditions are very poor. People are identified (they are taken their fingerprints), then depend on their status (irregular immigrant or asylum seeker ${ }^{13}$ ) they are displaced in different centers respectively CIE (Center of identification and expulsion) or CARA (Governmental first reception center). Nowadays, there are 16 CARA $^{14}$ widespread on the entire national territory. They are regulated by the national law LD 142/2015 which states that governmental first reception centers are managed by public local entities, consortia of municipalities and other public or private bodies specialized in the assistance of asylum applicants through public tender. Asylum seekers can go out from the center during the day, and they

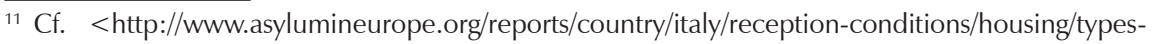
accommodation $>$.

${ }^{12}$ CPSA are locate in Agrigento (Lampedusa), Cagliari (Elmas), Lecce (Otranto) and Ragusa (Pozzallo).

${ }^{13}$ Asylum seekers can make their first request for an international protection already at CPSA when they declare their status.

${ }^{14}$ Cf. <http://www.cronachediordinariorazzismo.org/il-sistema-accoglienza-richiedenti-asilo-rifugi ati-italia/ $>$. 
can start looking for a job soon they receive the short residential permit which generally is after two months of living there. Asylum seeker should not stay long time in CARA center: as soon as there is a free place in SPRAR project, she/he is displaced there and can officially enter in the second-stage reception.

The System for Protection of Asylum Seekers and Refugees (SPRAR) consists of a network of managing entities that set up and run reception projects for people forced to migrate. At a local level the managing entity, with the support of the third sector (non-profit organizations, NGOs), ensures an integrated reception that goes beyond the mere provision of board and lodging. A wide range of services are offered: legal support, professional training, education, orientation measures, social assistance to facilitate the integration. Funding are provided through the National Fund for Asylum Policy and Services to the municipalities selected among those participating in the national competition. The presentation of the project by the municipalities is voluntary and foresees a cost- sharing mechanism. SPRAR's main objective is to take responsibility for those accepted into the scheme by helping them, with personalized programs, to (re)acquire self-autonomy and to take part in Italian society.

People can enjoy of SPRAR's benefits until the last decision of the Territorial Commission of recognition for international protection. Since, applications to take part in SPRAR project often exceed the number of available places; there is always a waiting list. According to the report published on Aida (Asylumlnformation Database) ${ }^{15}$, in the last five years, funding for SPRAR reception capacity has increased: from 3.979 places financed in 2011 to 20.965 for 2014-2016. Though the considerable growth, the current SPRAR's capacity is not sufficient to meet the accommodation needs, as SPRAR places cover only the $20 \%$ of the effective reception demand. For this reason, SPRAR centers are supplemented by emergency reception centers (CAS), which make up the greater part of the reception system. CAS constitutes a parallel system for second and first-stage reception centers. It is also used as alternative of CARA centers, since as aforementioned, they have little capacity to manage all the arrivals. Many asylum seekers remain in CAS center until the final decision of their international protection application. Therefore, many people never have access to second-stage reception center.

CAS centers were originally set up as emergency centers during the North African Emergency ${ }^{16}$. They are now part of the Italian reception system

15 The Asylum Information database is managed by the European Council on Refugees and Exiles (ECRE). Available on: <http://www.asylumineurope.org >.

${ }^{16}$ North African Emergency is the name given to the approach used by Italy to react to the huge number $(60,000)$ of people seeking protection in the course of the Arab Spring. The emergency lasted until the end of February 2013. 
and were institutionalized in Decree 142/2015 ${ }^{17}$ : CAS system designed as temporary and preparatory to SPRAR, has been expanded to the point of being absorbed in the ordinary system. CAS centers are identified by Prefectures ${ }^{18}$, that most of the time give the authorization to open a CAS center without taking in consideration the professional skills of the person who will manage it and if the conditions of the structure are appropriate to host asylum seekers. Management often lacks experience in dealing with asylum seekers and this is one of the main problem. There are constant changes to management and staff is often unqualified and/or overloaded ${ }^{19}$. Furthermore, often there is no publicly available list of centers, so their funding and mandates are not always transparent ${ }^{20}$. According to the annual report of "Médecins sans Frontières" many centers are very remote, overfull, unsuitable and hygienic standards are very poor. CAS centers with NGOs and local entities provide: language courses, legal and medical assistance. The services guaranteed are not as good as those in SPRAR project, and most of the time they are provided by volunteers. People can stay in CAS structures until their asylum request has been approved by the Commission or rejected for the second time ${ }^{21}$. The amount of the time they can still living on CAS center depending on its capacity and Prefecture's decision.

Once they leave CAS center, there is a high probability that they will end up living on street as claimed on the report of Médecins sans Frontières. People are forced to go out without any means to survive, so at the end they become homeless and invisible for the Italian society. This is what the Community of Sant'Egidio with its Humanitarian Corridor project wants avoid. Their aim is that people, once received the international protection, are economically independent and socially integrated, if not they can continue to be part of the program for a reasonable period of time.

So far, people with international protection are free to travel, but they do not receive any state support. The Italian system stipulates that they must be able to provide for themselves once they are granted of international protection and that during the time in CAS or SPRAR thanks to the services offered, they gained independence or at least the ability to apply for a job. Considering the current high level of unemployment in Italy, it is more or less impossible to find a decent work. If they manage, it is usually on the black market, which means

\footnotetext{
${ }^{17}$ Cf. <https://www.refugeecouncil.ch/assets/news/2016/161031-final-englisch-sfh-bericht-italienaufnahmebedingungen.pdf $>$.

${ }^{18}$ Cf. <http://www.asylumineurope.org/reports/country/italy/reception-conditions/housing/typesaccommodation $>$.

${ }^{19}$ Cittadinanzattiva, Libera and LasciateCIEntrare. InCAStrati: Iniziative civiche sulla gestione dei centri di accoglienza straordinaria per richiedenti asilo, February 2016, p. 26.

${ }^{20}$ MÉDECINS SANS FRONTIÈRES. Out of Sight. Report from March, p. 5.

${ }^{21}$ If the person appeals against a rejection receives the same status as an asylum seeker and can also stay in the center, until the next appeal commission.
} 
a temporary and low paid job. Therefore, the salary is likely not enough to rent a flat and to provide a secure income. This is why they could end up having no choice but to live on the street or in informal settlements (occupied buildings, shacks and tent camps). Under these circumstances, it is almost impossible for them to take part in integration measures, for example taking language or professional training courses. The situation is even worse for single mothers or fathers who must look after their children. According to the report of Médecins sans Frontières, the sustainable integration (promoted in CAS and SPRAR) is not realistic for most of the people with international protection, since they are around 70 percent of residents living in informal accommodation. It is evident that Italy does not have a coherent, comprehensive and sustainable reception system which is still based on short-term emergency measures and is highly fragmented. Moreover, it is almost entirely based on voluntary work and does not have transparent financial plan which allows the corruption to play an important role. People are completely left to fend for themselves and there is no different treatment for vulnerable people.

$\mathrm{HC}$ formula appears different from the beginning to the Italian hosting system. It provides a safe pathway, in line with governmental security standards: the potential beneficiaries are pre-selected by the NGOs based in loco, then vetted by the Ministry of the Interior and finally granted a humanitarian visa - for Italy only- before taking the flight. Once arrived, they find hospitality in different homes and shelters run by the three founding organizations in all the national territory. As well, they can start looking for a job, attending Italian language classes and social activities promoted by the volunteers of the three founding organizations and local entities in order to accelerate their integration process.

The first Humanitarian corridor arrival was greeted at Fiumicino airport (Rome) on 4 February, 2016. So far, more than 800 people ${ }^{22}$ (both Muslim and Christian) including minors safely arriving in Italy. They mostly came from Syria (Homs, Aleppo, Hama, Damascus and Tartous) and a minority from Iraq. They have lived, on average, for three years in Lebanon in a camp. Nowadays, 68 municipalities in 17 regions of Italy offered hospitality to the beneficiaries of the project and there are always more people who show their interest to welcome asylum seekers and help them to integrate in the local community.

Since the program has started, positive results can be seen on the reduction of the number of deaths on sea (a lot of people are applying for being $\mathrm{HC}$ beneficiaries instead of risk their life on sea journey) and on the attitude of Italian society over migrants. In fact, HC is contributing to make Italian society more open and pluralistic.

${ }^{22}$ Cf. GALEAZZI, Giacomo. Humanitarian Corridors, Sant'Egidio welcomes the most desperate in Europe. 


\section{Conclusions}

Humanitarian Corridors was born as a pilot project at the end of 2015, it was a risky investment in financial and human terms. Its big potential is his capacity to be a replicable model, however, according to Jeff Crisp, a research associate with Oxford's Refugee Studies Centre, it is not so certain that a lot of European countries will follow the Italian example. Crisp stressed: "despite initial evidence that private sponsorship can lead to better integration, it is too early to assess the effectiveness of the model. Other countries will be watching very carefully to see how these programs work out"23.

The motto of the Humanitarian Corridors campaign says "a few small drops can change the sea" 24 . The founders of the project are aware that one thousand people over two years is not a large number, but they are always saved life. Moreover, the main goal of $\mathrm{HC}$ is to give an input to politicians, to be the starting point of a solidarity project that involve all the international community.

Migration and asylum seekers' reception system are global and complex issues that require different actions in order to answer in a sustainable way. European governments should promulgate laws to facilitate the integration of new arrivals instead of trying stop migration flows. Face to the increasing number of deaths on Mediterranean Sea, and in particular after the tragedy of October 3, 2013, humanitarian organizations and initiatives from civil society have risen around all Europe. HC project promoted by Community of Sant'Egidio, Federation of Protestant Churches in Italy and Waldensian Diakonia and Methodist Churches is a good example of civil society's involvement. It is a bottom-up program which meets asylum seekers' needs and shows that an alternative and legal way to reach Europe is possible. As the Italian former Minister of Foreign Affairs, Paolo Gentiloni pointed out "Humanitarian corridors are a message to Europe to remind everyone that raising walls is not the solution" 25 . The project is very much in tune with the need to increase resettlement in the EU. The EU Agenda on Migration as well as the New York Declaration on Refugees and Migrants both support the development of alternative legal pathways to protection. Private sponsorship schemes, like this one, have the potential to contribute to the success and scaling up of resettlement programmes and are fully in line with current policy developments as it making use of humanitarian visas. Thorough pre-departure and post-arrival activities with strong community engagement are a key component of making legal pathways to admission for people in need of international protection work.

\footnotetext{
${ }^{23}$ SEWELL, Abby. A Humanitarian Corridor Provides an Alternative to Bombs and Boats.

${ }^{24} \mathrm{Cf}$. <http://openmigration.org/en/analyses/safe-legal-access-for-asylum-seekers-through-resettle ment-programmes-and-humanitarian-corridors/ $>$.

${ }^{25}$ Cf. Ibidem.
} 
As such, and, in comparison to other schemes, such as the European Resettlement Scheme mentioned above, the HC model is unique in that it is fully bottom-up, entirely promoted by civil society organizations who are offering governments a good practice that can be refined and strengthened through this action. It was praised by the Pope and high political figures in Italy who qualified it "a model of solidarity efforts in today's crisis which could be replicated in other States".

The Italian example has been formally followed by France which signed a Memorandum of Understanding to open Humanitarian Corridors on March 2017. The project is promoted by five organizations (Community of Sant'Egidio, the Protestant Federation of France, the Conference of Bishops of France, I'Entraide Protestant, and le Secours Catholique) and over the course of 18 months, France will welcome the safe arrival of 500 Syrian and Iraqi asylum seekers currently living in Lebanon. Also in this case, the priority will be given to the most vulnerable candidates. Beneficiaries will be welcome by communities, parishes, individuals, and they will receive support in order to have a fast and effective integration, thanks also to the learning of French language.

Humanitarian Corridor seems to be a good practice of civil society and a valid alternative to the political measures taken, nevertheless the program is probably too small to prevent many people from making sea crossing and it is too much selective. In conclusion, the three important aspects to keep in mind of $\mathrm{HC}$ are its focus on people who are in extremely vulnerable situation, the promoted hosting system and integration process and its replicable model for other European countries. This pilot project holds great potential as an innovative approach to the so-called 'refugee crisis' and to the new migratory crisis that will come in the future. A more durable radical solution for the current migration flows into Europe demands the opening of new channels of legal entry and the reinforcement of existing ones for refugees and asylum seekers, presumably the majority of people smuggled throughout the Mediterranean Sea. In our opinion, this should translate into, namely, granting humanitarian visas; the expansion of humanitarian corridors between transit countries and Europe; the expansion of European countries' resettlement programmes; and the development of alternative legal routes for refugees - such as family reunification, university fellowships and scholarships, training programmes, private sponsorships, and labour mobility. Humanitarian Corridors are a small step in order to remove a brick from the wall. The sealing and fortification of the EU borderland will not only mean the neglect of asylum seekers, but it will also favour the consolidation of smuggling networks. 


\section{References}

BHATIA, Monish. Seeking Refuge in Europe. 2017. Available at: <https://www. law.ox.ac.uk/research-subject-groups/centre-criminology/centrebordercriminologies/blog/2017/05/seeking-refuge > . Accessed on: 10.08.2017.

Council Directive 2001/55/EC of 20 July 2001 on minimum standards for giving temporary protection in the event of a mass influx of displaced persons and on measures promoting a balance of efforts between Member States in receiving such persons and bearing the consequences thereof. Official Journal L 212, 07.08.2001, p. 12-23.

COUNCIL OF EUROPE. European Convention for the Protection of Human Rights and Fundamental Freedoms, as amended by Protocols Nos. 11 and 14 . 04.11.1950, ETS 5. Available at: < http://www.refworld.org/docid/3ae6b3b04. html>. Accessed on: 15.07.2017.

Directive 2008/115/EC of the European Parliament and of the Council of 16 December 2008 on common standards and procedures in Member States for returning illegally staying third-country nationals. Official Journal L 348, 24.12.2008, p. 98-107.

Fran Quarterly (several years). Frontex. Available at: <http://frontex.europa.eu/ publications/?c=risk-analysis $>$. Accessed on: 10.08.2017.

GALEAZZI, Giacomo. Humanitarian Corridors, Sant'Egidio welcomes the most desperate in Europe. La Stampa, 05.06.2017. Available at: <http:// www.lastampa.it/2017/06/05/vaticaninsider/eng/inquiries-and-interviews/ humanitarian-corridors-santegidio-welcomes-the-most-desperate-in-europeFtO6Rm6VQHN9UmHepyEKoK/pagina.html>. Accessed on: 20.08.2017.

GUILD, Elspeth; MORENO-LAX, Violeta. Current Challenges for International Refugee Law, with a Focus on EU Policies and EU Co-operation with the UNHCR. Study written for the European Parliament. 2013. Available at: <http://www. europarl.europa. eu/RegData/etudes/note/join/2013/433711/EXPO-DROI NT\%282013\%29433711_EN.pdf>. Acessed on: 15.07.2017.

HELLER, Charles, JONES, Chris. Eurosur: saving lives or reinforcing deadly borders? Statewatch Journal, v. 23, n. 3/4, February 2014.

KATSIAFICAS, Caitlin. Asylum Seeker and Migrant Flows in the Mediterranean Adapt Rapidly to Changing Conditions. 2016. Available at: <http://www. migrationpolicy.org/article/asylum-seeker-and-migrant-flows-mediterraneanadapt-rapidly-changing-conditions > . Accessed on: 10.08.2017.

MALLARDO, Alberto. Humanitarian Corridors: A Tool to Respond to the Refugees' Crisis. 2017. Available at: <https://www.law.ox.ac.uk/research-subject-groups/ centre-criminology/centreborder-criminologies/blog/2017/05/humanitarian>. Accessed on: 10.08.2017.

MÉDECINS SANS FRONTIÈRES. Out of Sight. Report from March. 2016. Available on: <https://www.aerzte-ohne-grenzen.de/sites/germany/files/attachments/ aerzte_ohne_grenzen_out_of_sight_report.pdf $>$. 
Regulation (EC) No 562/2006 of the European Parliament and of the Council of 15 March 2006 establishing a Community Code on the rules governing the movement of persons across borders (Schengen Borders Code). Official Journal L 105, 13.4.2006, p. 1-32.

Regulation (EU) No 603/2013 of the European Parliament and of the Council of 26 June 2013 on the establishment of 'Eurodac' for the comparison of fingerprints for the effective application of Regulation (EU) No 604/2013 establishing the criteria and mechanisms for determining the Member State responsible for examining an application for international protection lodged in one of the Member States by a third-country national or a stateless person and on requests for the comparison with Eurodac data by Member States' law enforcement authorities and Europol for law enforcement purposes, and amending Regulation (EU) No 1077/2011 establishing a European Agency for the operational management of large-scale IT systems in the area of freedom, security and justice. Official Journal L 180, 29.6.2013, p. 1-30.

Regulation (EU) No 604/2013 of the European Parliament and of the Council of 26 June 2013 establishing the criteria and mechanisms for determining the Member State responsible for examining an application for international protection lodged in one of the Member States by a third-country national or a stateless person (Dublin III). Official Journal L 180, 29.6.2013, p. 31-59.

UNCHR. Global trends. Forced displacement in 2016. UNCHR, 2017.

SEWELL, Abby. A Humanitarian Corridor Provides an Alternative to Bombs and Boats, News Deeply, Refugees Deeply. 2017. Available at: <https://www. newsdeeply.com/refugees/articles/2017/04/27/a-humanitarian-corridorprovides-an-alternative-to-bombs-and-boats $>$. Accessed on: 10.08.2017.

Received for publication in August 28 ${ }^{\text {th }}, 2017$ Accepted for publication in September $25^{\text {th }}, 2017$ Recebido para publicação em 28.08.2017 Aceito para publicação em 25.09.2017 